Revue de recherche interdisciplinaire sur le genre et la sexualité

35 | 2018

Striges en tous genres

\title{
The Belgian Catholic Church and Canon Pierre de Locht on Sexuality after 1968: Moving Away without Breaking Away?
}

Caroline Sägesser and Cécile Vanderpelen-Diagre

\section{(2) OpenEdition}

Electronic version

URL: https://journals.openedition.org/sextant/399

DOI: 10.4000/sextant.399

ISSN: 2795-8736

Publisher

Éditions de l'Université de Bruxelles

\section{Printed version}

Date of publication: 1 December 2018

Number of pages: 101-115

ISBN: 978-2-8004-1636-6

ISSN: $1370-267 X$

\section{Electronic reference}

Caroline Sägesser and Cécile Vanderpelen-Diagre, "The Belgian Catholic Church and Canon Pierre de Locht on Sexuality after 1968: Moving Away without Breaking Away?", Sextant [Online], 35 | 2018,

Online since 01 November 2021, connection on 08 December 2021. URL: http:// journals.openedition.org/sextant/399; DOI: https://doi.org/10.4000/sextant.399

\section{(c) (†) (ㅇ)}

La revue Sextant est mise à disposition selon les termes de la Licence Creative Commons Attribution Pas d'Utilisation Commerciale - Partage dans les Mêmes Conditions 4.0 International. 


\title{
The Belgian Catholic Church and Canon Pierre de Locht on Sexuality after 1968: Moving Away without Breaking Away?
}

\author{
Caroline SÄGESSER and Cécile VANDERPELEN-Diagre
}

Canon Pierre de Locht (1917-2007) occupies an important place within the history of post-war Belgian Catholic world. De Locht's commitment to a Catholic Church that he wished open and welcoming to the realities of the faithful made him into a man of dialogue and openness, a leader of progressive Christians. At the time of Humance Vitce, de Locht, who had just published a book on the themes covered by the encyclical, found himself invested with the role of spokesperson for a laity that did not fully subscribe to the contents of Humanae Vitae. While the importance of de Locht's role is not always acknowledged in the written history of Catholicism and the Belgian Church, his importance is reflected, to this day, in the memories of the faithful in this country. In 2007, a large crowd attended his funeral, a ceremony where several political and religious figures took the floor, and many tributes were published in the press. More than ten years after his death, it is interesting to reflect on the strategies adopted by the charismatic canon to try to find ways for believers to remain within the Catholic Church while dissociating themselves from some of its dogmas, on one of the most emblematic issues of the history of contemporary Catholicism, the "Republic of the intimate", as it is called by Denis Pelletier ${ }^{1}$. It is also worth examining the attitude of the clerical authorities towards de Locht before and after Humance Vitce, bearing in mind that conflicting views on human sexuality and morality were not the only issue in a conflict where questions of authority and obedience played an essential part as well.

${ }^{1}$ D. Pelletier, "Les évêques de France et la République de l'intime (1968-2005)", in C. Béraud, F. Gugelot and I. Saint-Martin (ed.), Catholicisme en tensions, Paris, ehess, 2012, p. 179-189. 


\section{A Catholic Country with a Firm Progressive Tradition}

To understand how and why Pierre de Locht came to be followed by so many believers, it is important to note that he was born in a country where the Catholic Church had a strong progressive tradition. Already in the first years following independence (1831), Belgian bishops took it upon themselves to give full support to the liberal Constitution of the new state, including freedom of religion and worship for all, and disregarded instructions coming from the Vatican, despite the publication of the encyclical Mirari Vos in condemnation of modernity ${ }^{2}$. Throughout the 19th century, the Church and the Catholic party played an important part in the development of the country. After WWI, Belgian Catholicism began to reflect actively on the changes brought about by modernity. In the 1930s, some initiatives took place inside the Church to reflect upon the impact of modernity on Catholicism, and more specifically on Catholic families. After World War II, they resumed with additional motivation, searching for new ways for lay men and women to live up to the gospel's message and to take on responsibilities within the Church $^{3}$. It is important to bear in mind that Belgium remained a highly Catholic country; other Christian denominations and Judaism constituted extremely small minorities in the country, and while Freethinking societies and an anticlerical spirit were firmly rooted in the land since the mid-19th century, it would not be until the 1970s that church attendance would significantly drop. In the early 1960 s, more than $90 \%$ of Belgians were baptized in the Catholic Church, more than $90 \%$ of funeral ceremonies took place in a church where more than $80 \%$ of couples still got married ${ }^{4}$. The number of priestly vocations would not decrease until after Vatican II.

Belgian society in the 1960s still harboured a very powerful "Catholic pillar": education (with a majority of the schools being confessional), healthcare, youth organizations, trade unions, charities... bore the imprint of the Church. Even political life had taken on a Catholic colour: the long-established Catholic party had enjoyed a near permanent presence in government since the end of the 19th century, most of the time in partnership with the Liberals or the Socialists: it played a truly pivotal role on the political scene. Nevertheless, the Catholic party had transformed itself after WWII, becoming in 1945 the Social-Christian Party (CVP-PSC), breaking its organic ties with the Church. While the new CVP-PSC was a non-confessional party, for which the main reference was now personalism, the influence of the Church on the party remained very much a reality ${ }^{5}$. At the 1946 elections, the party emerged immediately

2 This has been well documented by canon Simon. See A. Simon, L'Eglise catholique et les Débuts de la Belgique indépendante, Wetteren, Edition Scaldis, 1949; Le Cardinal Sterckx et son temps, Wetteren, Editions Scaldis, 1950; Rencontres menaisiennes en Belgique, Bruxelles, Académie royale de Belgique, 1963.

3 J.-L. JADOULle, Chrétiens modernes? L'engagement des intellectuels catholiques "progressistes" belges de 1945 à 1958, Louvain-la-Neuve, Academia-Bruylant/Presses universitaires de Louvain, 2003.

${ }^{4}$ F. Houtart, "Belgique, terre de chrétienté?", in Cl. Soetens (ed.), Vatican il et la Belgique, Louvain-la-Neuve, Presses universitaires de Louvain, 2012, p. 73.

5 See P. Delwit, La vie politique en Belgique de 1830 à nos jours, Bruxelles, Editions de l'Université de Bruxelles, 2009, p. 108-110; Un parti dans l'Histoire. 1945-1995. 50 ans 
as Belgium's largest political force, crushing the little Democratic Union (UDB) which had formed to its left on a multi-confessional basis.

Yet, a gentle wind of reform was blowing on the Belgian Catholic World after WwII; progressive theologians were meeting at the Catholic University and in other institutions of higher learning (Lumen Vitce), advocating reforms, especially with regard to liturgy, and conducting a dialogue with other Christians and non-believers ${ }^{6}$.

Belgian bishops and theologians played a very active part in the preparation of Vatican II, and during the council the "Belgian squadra" became known in Rome for its activism. The Belgian mark, and more specifically that of Cardinal Suenens, archbishop of Brussels-Mechelen, ware thought to be particularly heavy on the constitution Lumen Gentium, which would open the door to a more active role for God's people - the laity ${ }^{7}$. While some Belgian Catholics were disappointed by the outcome of Vatican II, deeming it too timid, most embraced the proposed changes with enthusiasm. One of the most welcome aspects at the time was indeed the proposed new role for the laity within the Church. When Humanae Vitae was promulgated a few years later (1968), it hit the reformers like a cold shower; indeed, many of them had been involved in groups reflecting on new approaches to the meaning of marriage, sexuality and fertility. The strict prohibition of "artificial means" of birth control maintained by Rome did not fit into those groups' new attitude towards marriage, just as it did not fit as a whole in a society that was going through the sexual revolution. Simultaneously, a process of reassessing the bishops' authority, and through theirs, that of Rome, was set in motion. Catholic laity, and the many grassroots movements they had started since the mid-1940's as part of the expected grand rejuvenation of Catholicism in Belgium, were now taken aback both by the reaffirmation of conservative postures on sexuality, marriage and fertility, and by the attempts of the clergy to remain in control of all Catholic organizations ${ }^{8}$.

\section{From Hero to Black Sheep}

Playing an active part in these processes was Canon Pierre de Locht, a theologian and Catholic priest who was a member of the pontifical commission on Population, Family and Birth (1964-66) ${ }^{9}$. Since 1946, de Locht had been active in lay groups (such as Equipes Notre-Dame) and publications (Feuilles familiales) aimed at defining new spiritual approaches to marriage and sexuality while giving couples and families a more active role in the life of the Church. In 1959, at the request of ecclesial authorities, de Locht founded the Centre national de pastorale familiale (CEFA) and

d'action du Parti Social Chrétien, (collect.), Louvain-la-Neuve, Duculot, 1996.

${ }^{6}$ J.-L. JADOUlLe, "Les visages de l'Eglise de Belgique à la veille du concile Vatican II", in Cl. Soetens (ed.), Vatican II et la Belgique, Louvain-la-Neuve, 2012, p. 11-70.

7 A. Prignon, "Evêques et théologiens de Belgique au Concile Vatican II", in Cl. SoEtens (ed.), Vatican II et la Belgique, Louvain-la-Neuve, Presses universitaires de Louvain, 2012, p. 141-184.

${ }^{8}$ L. Gevers, Kerk in de kering: de katholieke gemeenschap in Vlanderen, 1940-1980, Kalmthout, Pelckmans, 2014.

${ }^{9}$ Born in Brussels into a Catholic bourgeois family, Pierre de Locht (1916-2007) was a Catholic priest and doctor in theology. 
began teaching conjugal ethics at the Institut des sciences familiales et sexologiques, which was part of the medicine faculty of the Catholic university of Louvain. De Locht took a progressive stance on issues like priests' marriage, contraception and even (later) abortion. Initially welcomed by the Church's hierarchy, de Locht's action was gradually looked upon with suspicion. After 1968 and the publication of Humance Vitce, de Locht's positions were clearly no longer in line with those of the Church. The Belgian bishops no longer gave their imprimatur to de Locht's abundant literary production, and in 1978 they attempted to have him banned from the university: they advised the competent disciplinary committee of the university to dismiss de Locht, but the committee, after a month's deliberation, refused. Nevertheless, de Locht's career in the academic world was undoubtedly harmed by this action; he never achieved full tenure. At the same time, his popularity grew in Catholic circles and beyond; his books enjoyed wide circulation and were translated into many languages.

Despite losing favour at times, especially after his stance in favour of the decriminalization of abortion, it must be emphasized that the canon was never publicly disowned by the Church. In a nutshell, it could be said that he was ostracized but not excommunicated.

In addition to the many clerical friends who shared his views, de Locht enjoyed the high esteem of members of the highest clerical authorities, including the current archbishop of Mechlin-Brussels, Jozef de Kesel, who delivered a keynote speech at the funeral ceremony. And for good reason: the canon never directly attacked the Church.

\section{Humance Vitce}

On July 15, 1968, ten days before the release of the encyclical Humance Vitce, de Locht published his book La morale conjugale en recherche ${ }^{10}$. The first print-run of 4,000 copies was very quickly out of stock. The publisher, Casterman, reprinted 2,000 copies ${ }^{11}$. This constituted a major draw for Belgium. In this book, de Locht argues that the criterion of morality does not lie in the physiological process of the conjugal act, but in the quality of mutual care and love which the spouses demonstrate.

De Locht was wary of a legalistic morality that imposed non-intervention as the only acceptable method of contraception. However, aware of the transgression contained in his text, he asked the Vicar General of the Archdiocese of MechelenBrussels for permission not to submit to the imprimatur; his request was granted.

Comme je vous le disais, il me semble qu'il serait beaucoup plus souhaitable de ne pas le soumettre à l'Imprimatur, non pour me soustraire à un contrôle, (je l'ai fait

${ }^{10}$ De Locht applied pressure on his publisher for the book to come out before the encyclical, in order not to be in open contradiction with the Pope (UCL, Archives de Locht, Dossier: Mes livres I, 127, dossier Morale conjugale en recherche). However the book was distributed after the publication of Humance Vitce. Hence the insertion of a publisher's note stating: "Ce livre est sorti de presse le 15 juillet 1968. La période des congés n'a pas permis qu'il soit distribué plus tôt. La Morale conjugale en recherche essaie de cerner toute l'interprétation actuelle. L'encyclique Humance Vitce n'a rien enlevé à cette interrogation".

${ }^{11}$ UCL, Archives de Locht, Dossier: Mes livres I, 127, dossier Morale conjugale en recherche. 
lire et revoir), mais parce qu'il s'agit d'un ouvrage publié sous ma seule responsabilité personnelle.

En faisant cela, je m'engage directement moi-même, mais je crois qu'il n'est pas raisonnable de faire prendre d'une certaine façon, à son compte, par l'Evêque, par le Magistère, un livre de recherche.

Il n'y a rien d'ailleurs de si bousculant dans ce livre ; j'essaye simplement de faire le point loyalement et d'exprimer comment je perçois les données actuelles du problème. Il me semble, après 20 ans de travail et de recherche dans ce domaine, devoir faire ce bilan. Si vous le désirez, je suis d'ailleurs tout disposé à vous envoyer le texte ${ }^{12}$.

This letter is an important document because in it, we see condensed the great project that de Locht had set out early in his career: to reconcile the official doctrine of the Church and his ministry on marriage and family. During a first period, de Locht attempted to reform the doctrine and to create an essentially inductive moral theology, elaborated while listening to lay Christians. But his stance turned out to be problematic, or frankly impossible. It was nothing less than an attempt to solve what Bergson called "the ancient conflict between idealism and realism". De Locht failed, and during a second period he turned resolutely towards lay people, bringing to the faithful the relief of his inductive morality.

In January 1967, de Locht was invited to give a lecture on birth control by the Centre catholique des intellectuels français (CCIF). Founded in 1941, the Centre was a very dynamic think tank in the post-war years, eager to confront the teachings of the Catholic Church with modernity, "pour habiller la pensée catholique d'un costume moderne" ${ }^{13}$. In his conference, de Locht maintained that it was impossible for Catholic couples to wait for new instructions from Rome and simply continue to respect the general prohibition on "artificial" birth control. For de Locht, the issue of birth control must be thought of as an element of the development of the harmony in the conjugal life of Christian couples, and he appears convinced that the Church authorities are carefully considering it in this light ${ }^{14}$.

The publication of Humance Vitce came as a profound shock to de Locht as to many contemporaries; between the establishment of the Pontifical Commission on Birth Control by John XXIII and the publication of the encyclical, five long years passed during which God's people were forced to handle the various aspects of marital life, and furthermore, during which indications - the clearest being the (unauthorized)

12 Pierre de Locht to Monseigneur Paul Theeuws, Idem, June 1968.

13 Internal document from 1946, quoted by C. GuYoT, in "La création du Centre catholique des intellectuels français : une nouvelle approche du monde profane par les intellectuels catholiques?", Revue d'Histoire de l'Eglise de France, 84/213, 1998, p. 331. On the CCIF, see C. Toupin-Guyot, Les intellectuels catholiques dans la société française: le Centre catholique des intellectuels français, 1941-1976, pref. by René Rémond, Rennes, Presses universitaires de Rennes, 2002.

14 «La régulation des naissances », lecture delivered at CCIF, Paris, 23 January 1967. « Papiers Lestapis », Archives des Jésuites de France, Commission pontificale et «médecins et morale sexuelle », kindly provided by Mrs Martine Sevegrand whom we sincerely thank. 
publication of the reports of the Pontifical Commission - gave him to believe that a relaxation of the position of the Church in this regard was to be expected. De Locht was convinced that it was unthinkable that the Church should stick to old positions. Thus, for him, it had become important

d'aider surtout les plus conservateurs des époux, ceux qui avaient mis toute leur générosité dans une application ponctuelle des prescriptions officielles, à s'ouvrir à une compréhension plus profonde de la responsabilité morale ${ }^{15}$.

In 1966, he published La Morale conjugale à la lumière du concile ${ }^{16}$, in which he stressed that these were times for personal responsibility. In his book Morale sexuelle et magistère, de Locht confessed that he asked himself repeatedly during the days following the publication of Humance Vitce about the meaning of his loyalty "as man, as Christian and as priest", concluding that it commanded him to admit his reservations about the document ${ }^{17}$.

And he did so publicly, including in television programmes on the topic of the day, Humance Vitce. On August 7, 1968, shortly after the publication of the encyclical, the programme " $9,000,000$ ", hosted by Belgian TV anchorman Henri-François Van Aal confronted de Locht with Mgr Victor Heylen, professor of moral theology at the Catholic University of Leuven and secretary of the doctrinal council established by the Belgian bishops. While Heylen, joined by Father Martelet, a French priest from the diocese of Lyon, defended the encyclical and advocated obedience to the Pope, de Locht made it plain that he considered his duty to the Church to voice his deep concerns about its contents ${ }^{18}$.

Two conceptions of Christian morality were hence put to the public: that of Humance Vitce and that of Pierre de Locht... The latter became the target of much criticism for his disdain for obedience, by fellow priests and in the columns of the Catholic newspaper La Libre Belgique. One of them, Father Carpentier, a Jesuit, expressed his surprise, in retrospect:

cela restera un étonnement de l'histoire qu'on ait pu, en ce pays catholique, de fidélité au pape bien connue, enseigner ouvertement la contraception, qui est contraire à la loi naturelle morale, et que ceux qui enseignaient cela étaient des prêtres ${ }^{19}$.

If, for conservatives like Father Carpentier, Humance Vitce closed the parenthesis of individual moral research, for many, including de Locht and CEFA, la messe n'était pas encore dite ${ }^{20} \ldots$

${ }_{15}$ P. DE Locht, Morale sexuelle et Magistère, Paris, Les Editions du Cerf, 1992, p. 41.

${ }^{16} \mathrm{P}$. DE Locht, La morale conjugale à la lumière du Concile, Bruxelles, Centre national de Pastorale familiale, 1966.

${ }^{17}$ Morale sexuelle et magistère, op. cit., p. 47.

${ }_{18}$ Transcript from the TV broadcast "9.000.000", August 7, 1968, about "Humance Vitce", "Papiers Lestapis", op. cit.

19 "Une libération de quatre ou cinq années d'esclavage", La Libre Belgique, 29 août 1968.

20 "mass had not yet been said", a French expression implying that the discussion was not yet closed. 


\section{The Willy Peers Affair}

In the early 1970s, de Locht's position within the Church was becoming gradually less and less comfortable. While Paul vi may have already asked Cardinal Suenens to dismiss de Locht as head of the CEFA shortly after Humance Vitce ${ }^{21}$, the Belgian bishops would not take action until the early 1970s. By then the position of de Locht on abortion would constitute another casus belli. In January 1972, the bishops asked him to hand in his resignation; his refusal, and the support publicly displayed by many, including the Brussels Presbyteral Council in November ${ }^{22}$, induced a compromise: the bishops' conference released a statement with the aim of distancing themselves from the work of CEFA:

Les évêques francophones désirent trouver une solution pratique qui leur permette de continuer à porter leur responsabilité pastorale et doctrinale en encourageant la réflexion sur les problèmes qui se posent, mais aussi sans couvrir de leur autorité tout ce qui se publie et se dit, même parmi les animateurs de la pastorale familiale ${ }^{23}$.

By then, de Locht was very much a public figure, and the bishops' statement was commented on Belgian national television the day after, in "les Dossiers de l'actualité", with de Locht and the spokesperson for the bishops, Father Pirlot.

Yet the troubles of the canon were far from over. In January 1973, La Revue Nouvelle published a lengthy article about the conflict, analysing the link between a model of authority and the sexual questions under discussion ${ }^{24}$.

Simultaneously, the "Willy Peers" affair was unfolding and would be the next step in the estrangement of de Locht from the Catholic establishment. By deciding to attend the demonstration on January 27, 1973, protesting against the imprisonment of the physician who had admitted to performing many abortions, de Locht would once again publicly expressed his disagreement with the authorities. De Locht would later recall that his existence had been shaped by those two crucial moments: his decision to voice his reservations after the publication of Humance Vitce and his decision to go public with his support for Willy Peers:

Ce furent les deux choix fondamentaux ; tout le reste se situe dans la logique de ces engagements décisifs. (...) Ces deux instants cruciaux ont orienté le reste. J'ai opté, à ces deux tournants, pour des valeurs ; j'ai posé un geste de conviction, auquel tout le reste s'enchaîne. J'en paie, depuis, le prix... et les grâces ${ }^{25}$.

The price paid by de Locht included facing threats to be banned from UCL at the bishop's request acting upon Rome's orders and never obtaining full tenure at the faculty. In 1977, it became known that Rome wanted de Locht to renounce his teaching position at the Catholic University (UCL). The university authorities decided to submit the question to the disciplinary commitee, since it concerned a member of

${ }^{21}$ Morale sexuelle et magistère, op. cit., p. 53.

${ }^{22}$ Conseil presbytéral de Bruxelles, motion adopted on November 28, 1972, published in Morale sexuelle et magistère, op. cit., p. 87.

23 Press release from the Bishops'Conference, December 7, 1972.

24 La Revue Nouvelle, March 1973.

25 Morale sexuelle et magistère, op. cit., p. 101. 
the academic staff. A majority of the academic staff supported de Locht, on the grounds of respect for "academic freedom, independence of the university and integrity of persons attached to the university in their professional and individual rights". The board decided to stay the proceedings. Simultaneously, a commission of theologians appointed by the bishops was examining the case. This commission submitted its findings at the end of 1979, at a time when Cardinal Suenens, having reached the age limit, tendered his resignation. This change at the head in the Belgian Church may have played a part in the dismissal of further proceedings against de Locht.

\section{Personalism and Sexuality}

From 1946 on, de Locht was doing fieldwork. Meeting with secular families had been for him a real "turning point in [his] ethical vision". He realized that bringing a ready-made truth was irrelevant. "Je n'ai plus pu être seulement le porte-parole de vérités élaborées ailleurs, ni le gardien scrupuleux de normes institutionnelles en partie dépassées par la vie" ${ }^{26}$.

In this, he obviously showed himself to be the heir to the French personalist movement, which had had enormous influence in Belgium - Emmanuel Mounier, married to a Belgian, having lived there for several years.

This philosophical movement advocated apprehending humankind through its historical and unique dimension and proposed an alternative to modern individualism. To appease social tensions, Christians advocated an interpersonalist dynamic, intersubjective in social relations (notably against the class struggle).

As shown by Wannes Dupont ${ }^{27}$, personalism had deeply influenced the neoThomist Philosophy Institute of the Catholic University of Louvain, and this had an impact on the way moralists apprehended sexuality. The most active in this area was Louis Janssens (1908-2001). The theologian moved away from Thomists who focused on the biological purpose of marriage, the reproductive function having to benefit the common good.

In 1958 already, de Locht stated that chemical inhibition of ovulation was not "necessarily immoral". From the pastoral point of view, it is especially Jacques Leclercq who influenced Canon de Locht. A widely respected intellectual, Leclercq was the founder of La Cité chrétienne ("the Christian City") and the initiator of modern sociology at the Catholic University of Leuven. Leclercq was also involved in marital pastoral. He helped launch the movement of Equipes Notre-Dame ("Teams of Our Lady") in Belgium.

In 1947 Leclercq published a book, Mariage chrétien ("Christian marriage"), which became a bestseller (5 French editions and translations in Spanish, English, Italian, German and Portuguese). The book appealed to readers because Leclerq did not drown them in complicated dogmatic considerations. Rather, he drew his

${ }^{26}$ Speech by Pierre de Locht at the party organized for his 50th priesthood anniversary, 15 September 1990, quoted by J. Debelle, "Un homme du grand large”, in J. Debelle (dir.), Rue de la Pré-Voyance. Essais sur la pensée de Pierre de Locht, Malonne, Feuilles familiales, 2001, p. 24.

${ }^{27}$ W. Dupont, "Catholicisme et évolution des mœurs sexuelles dans la Flandre belge", in A. Giami and G. Hekma (ed.), Révolutions sexuelles, Paris, La Musardine, 2015, p. 329-352. 
teachings from the testimony of experiences. Moreover, he did not dwell on the subject of "forbidden flesh" to focus on love, and admitted that "no birth control" was no longer a realistic option. De Locht, who wrote a laudatory article on the book when it appeared ${ }^{28}$, would build on the clear tone of his master in his own writings. As for Leclercq, he considered de Locht as his spiritual son on these issues ${ }^{29}$.

For de Locht, as open as it can be, the pastoral ministry was not limited to receiving and listening to Christians who came to him. Never did he give up delivering a moral message. Continence and temperance remained the guidelines, but, and this is where the difference lies, they did not constitute binding laws. Therefore, together with the lay team around him at CEFA, he set up a set of services to guide men and women seeking help or answers: marital consultations.

Couples could also find answers to their questions in the Feuilles familiales, the magazine of CEFA. These included letters from readers ${ }^{30}$. While only a selection of them were summarized and reproduced in the magazine, all the letters received have been preserved in the archives of Pierre de Locht, along with the anonymous answers sent by the drafting committee.

These letters tell us that the "de Locht team" applied a very precise methodology: encouraging believers to shed guilt and the need for a sex life modelled on dogma. Instead, they were encouraged to follow a path. Continence must be an ideal, and the path to get there was what mattered and where lied the path to holiness. Not achieving it in this life did not constitute a sin. The letters tell us that the concerns of penitents mainly concerned the practice of onanism. The members of CEFA attempted to replace it by the combined methods of Ogino and temperatures. Many letters indicate that the method was not a panacea and some members of CEFA came to acknowledge this.

CEFA members were also confronted with the constant demand from believers to have guides, brochures, to lead them on the path of Christian conjugal morality. To meet this persistent demand would in a way violate the principle of the group not to publicly disclose the advice given: to publicize the outcome of the consultations would be to give them a sense of generalized truth, contrary to the principle of consultations adapted to each case.

Nevertheless, de Locht and his friends began writing clear and concise manuals, aimed at the widest possible public, and covering every aspect of marital and family life. In 1973 the collection Amour humain ("human love") was launched by the Parisbased publishing house Centurion. Founded in 1945, Centurion was a branch of the Maison de la Bonne Presse (which would become Bayard in the late 1960s), run by the Assumptionist fathers. The goals set for this editorial project were vast:

Il me paraît très important que cette collection soit marquée par un réalisme serein sous-tendu par une espérance fondamentale.

${ }^{28}$ P. SAuvage, Jacques Leclercq 1891-1971: un arbre en plein vent, Louvain-la-Neuve, Duculot, 1992, p. 218-219.

${ }_{29}$ Jacques Leclercq to Pierre de Locht, 25 May 1961, quoted in P. Sauvage, Jacques Leclercq, op. cit., p. 315.

${ }^{30} \mathrm{Ph}$. Denis, "Le couple et la famille au prisme d'une revue. Histoire des "Feuilles Familiales" (1938-1975)", Revue d'histoire ecclésiastique, LXxxiv-2, 1989, p. 390-403. 
Personnellement, je ne crois pas que notre civilisation se détériore, elle porte au contraire en elle de nombreuses forces neuves. Il importe, non de freiner l'évolution, mais peut-être de l'accélérer pour faire mûrir tant de possibilités qui se cherchent. Pour cela, notre époque a besoin de confiance dans ses véritables possibilités. Une réflexion réaliste sur l'homme peut susciter cette confiance et la foi chrétienne, y apporter des motifs complémentaires et ultérieurs. C'est dans cet esprit que la collection pourrait faire œuvre très utile, à propos de thèmes qui nous concernent tous ${ }^{31}$.

The visibly very free tone used can be explained by the fact that for a few months, CEFA had no longer been "appointed" by the clergy. Since 1968, its publication Les Feuilles familiales no longer received the Imprimatur. One observer noted:

si cette nouvelle situation lui permet de mener avec plus de liberté encore recherche et action, le CEFA entend conserver son orientation chrétienne et participer loyalement à la vie de l'Eglise. Il le fait de multiples manières: sessions de formation pour éducateurs et conseillers conjugaux, actions auprès des fiancés ou des jeunes, recherche plus fondamentale, etc. ${ }^{32}$.

This even greater focus on fieldwork was probably the formula adopted to bring the team closer together. Indeed, in the aftermath of Humance Vitce and following internal dissension, CEFA experienced a real crisis. De Locht offered a fresh start, based on research. He explained this in an interview at the press conference marking the launch of the collection:

Ensemble nous avons essayé de réfléchir aux visages (vous remarquez avec "s"), aux visages nouveaux que pourrait prendre ou qu'est en train de prendre la famille. Mettre en question ne signifie ni démanteler ni rejeter, mais décanter, réinventer, en accueillant l'aventure de l'humanité, c'est-à-dire en étant hardiment tourné vers ce qui vient ${ }^{33}$.

These sentences are an obvious reference to the idea of a Church attentive to the "signs of the times", dear to the Council Fathers of Vatican II. A dimension that de Locht intended to explore.

\section{Ecclesia Docens vs Ecclesia Quaerens}

One will recall the title of the book La morale conjugale en recherche. The "searching" dimension had been put forward to avoid confrontation with the Church. But the use of the term was beyond circumstantial; it had a much more programmatic function.

It is difficult to determine which scientific and theological currents most influenced the thinking of de Locht. His library has been dispersed and his desire to be concise and to write for the general public prompted him to put only a few notes in his writings.

${ }^{31}$ Pierre de Locht to his "dear friends" from CEFA, 23 January, 1973, UCL, Archives Pierre de Locht, Dossier Editions du Centurion, 22.

32 GCdm, "Famille. Du côté du CEFA", La Cité, 11/12 October 1975.

${ }^{33}$ Interview of Pierre de Locht, in J.-L. MarChIERE, " Amour humain. Une nouvelle collection », Actuels-livres, 15 November 1975. 
However, it is very likely that de Locht's involvement in research was a response to one of the men who most influenced the Catholic intellectuals of the years 1950s: Teilhard de Chardin. In 1917, the Jesuit paleontologist deplored that the Church did not have a research arm. "Il faut que sous le contrôle de l'Ecclesia docens s'organise, se développe, $l$ 'Ecclesia quaerens 34 ".

It was not until 1965 that this formula was published and enjoyed a resounding success in the Catholic world. It must be said that it was perfectly in line with the general orientation of the Catholic intellectual and scientific fields of the time. After the war, the laity, better educated than its ancestors thanks to the democratization of learning, requested innovative work enabling dialogue with the contemporaries, including agnostics and atheists. For their part, Catholic officials are determined to conquer both the elite and the masses ${ }^{35}$. Humanities, essentially sociology, were thought of as useful tools of evangelization. In the post-war process of institutionalization of sociology, the Catholic University of Leuven did not want to be outdone and gave itself the means of an operational presence ${ }^{36}$.

The issues of birth control and organization of the family were tackled head on by the university. The Economic and Social Research Institute (IRES) developed studies centered around the family. The resulting publications were surveys on households and professional behavior of the couple and of the family (mainly based on demographic and economic data) ${ }^{37}$. In 1961 an Institute of Family and Sexology Sciences was founded within the Faculty of Medicine under the leadership of Cardinal Suenens. Here, investigations attempted to deepen biological, physiological, psychological and sexological issues ${ }^{38}$. From 1967 on, de Locht was in charge of the course "Ethique des problèmes de population" at the Institute.

University studies gathered by these two institutes were obviously the extension of the methods of evangelization by investigation inaugurated in the 19th century by Le Play. They would be widely used after him by many Catholic social entrepreneurs ${ }^{39}$.

They were also at the heart of the action of the Jeunesses ouvrières chrétiennes JOC (Christian Youth Workers). For its founder, the Belgian priest Joseph Cardijn, efficiency of action depended on adequate training, in order for the activist to be able to establish devices suitable to the terrain. His conviction was inspired by the empirical sociology teaching received at the Catholic University of Louvain and was

${ }^{34}$ Letter to P. Fontoynont, 26 July 1917, in Science et Christ, Paris, Seuil, 1965, p. 30.

35 E. Foullloux, Une Eglise en quête de liberté: la pensée catholique française entre modernisme et Vatican II, 1914-1962, Paris, Desclée De Brouwer, 1998, p. 196-198.

${ }^{36}$ C. VANDERPElen-Diagre, "Dire l'humain avec des chiffres. CEuvres et engagements des sociologues de l'Université catholique de Louvain (1939-1970)", Archives des sciences sociales des religions, Dossier Sociologies catholiques, 179, octobre-décembre 2017, p. 129146.

37 Ibid.

${ }^{38}$ L. TIERENS, 'T moet van twee kanten komen. De verhouding tussen katholicisme en wetenschap bij de oprichting van het Instituut voor Familiale en Seksuologische Wettenschappen, Master's thesis in History, Katholiek Universiteit Leuven, Leuven, 2014.

39 D. Pelletier, "Engagement intellectuel catholique et médiation du social. L'enquête monographique de Le Play à Lebret”, Mil neuf cent, 13, 1995, p. 25-45. 
formulated in the famous motto "see - judge - act". Within the Joc, each local section is equipped with a central study circle and massively used the survey method. Any militant therefore had to go through a "social school" ${ }^{40}$.

Empirical methods and research development constitute the backbone of de Locht's reflection; in this he shows himself to be the worthy heir of the conciliar fathers who framed the Constitution Gaudium et spes. Indeed, the Constitution states:

Les progrès des sciences biologiques, psychologiques et sociales ne permettent pas seulement à l'homme de se mieux connaître, mais lui fournissent aussi le moyen d'exercer une influence directe sur la vie des sociétés, par l'emploi de techniques appropriées ${ }^{41}$.

We find the same ideas in principle in all the publications of de Locht, who never ceased to repeat that one must listen to the contributions of sociologists, psychologists, biologists and moralists before understanding what the family may be and judging the moral value of a couple's behaviour and intentions: "Il n'est plus possible de s'interroger sur la famille sans élargir son angle de vue et faire appel à différentes analyses" ${ }^{42}$.

We must note that this approach comforted the laity, deeply shaken by the very severe clerical positions. After the publication of Morale conjugale en recherche and Humance Vitce, a French couple deeply involved in accompanying families talked about de Locht's book as "a beacon in the night ${ }^{43}$ ". In the same circumstances, the wife of a Brussels gynaecologist wrote this significant letter:

Nous adhérons sans restrictions à la recherche que vous y professez.

Après la parution d'Humance Vitce et les réactions que ce document a suscitées, la lecture de votre livre est comme un baume sur une blessure ouverte et un encouragement à persévérer dans la voie qui nous paraît vraiment la seule digne de l'homme et promotrice d'un épanouissement conjugal réel.

Comme vous, nous avons été abasourdis, déçus au-delà de toute expression, révoltés même, bafoués dans une recherche qui nous touche personnellement certes, mais surtout professionnellement, et où nous sommes certains d'avoir découvert les vraies valeurs en jeu ${ }^{44}$.

${ }^{40}$ E. GÉRARD and P. WynANTS, Histoire du mouvement ouvrier chrétien en Belgique, Leuven, Leuven University Press, 1994.

${ }^{41}$ Pastoral Constitution on the Church in the Modern World Gaudium et Spes promulgated by his Holiness, Pope Paul vi on December 7, 1965 (http://www.vatican.va/archive/hist councils/ii_vatican_council/documents/vat-ii_const_19651207_gaudium-et-spes_en.html), accessed on August 12, 2016.

${ }^{42}$ P. De Locht, "Préface", in P. De Locht, O. Thibault, P. Delooz, M.-Th. Van LunenChenu, Visages de la famille, Paris, Centurion, 1975.

${ }^{43}$ For reasons of confidentiality, we cannot name the persons mentioned. Letter to Pierre de Locht, 5 September 1968, ucL, Archives Pierre de Locht, Dossier: Mes livres I, 127.

${ }^{44}$ Letter to Pierre de Locht, Brussels, 30 August 1968, UCL, Archives Pierre de Locht, Dossier: Mes livres I, 127. 


\section{Crystallizing Other Issues?}

Humance Vitce may be seen as the confirmation of a global viewpoint of the Church on sexuality, beyond the prohibition of artificial birth control.

De Locht underlines how much the teachings of the Catholic Church on sexuality are removed from reality:

Le secteur d'apostolat dans lequel j'ai été engagé, la pastorale familiale, est un de ceux où la distance entre la réalité vécue et l'enseignement de l'Eglise se fait le plus sentir.

And he explains it as follows:

Est-il étonnant qu'une institution uniquement gérée par des hommes, ayant tous, au moins dans l'Eglise latine, adopté obligatoirement un style de vie d'exception, ait une perception unilatérale de la sexualité ${ }^{45}$ ?

As outlined by Danièle Hervieu-Léger, since the 19th century the Church has attempted to regain the ground lost in terms of political power by focusing its energy on controlling people's intimacy ${ }^{46}$. Beyond the prohibition of artificial birth control, Humance Vitce reaffirmed the authority of the Church on every aspect of the life of the faithful, even the most intimate.

The encyclical also appeared as a negation of the opening to the laity announced at Vatican II, and was evidence of a deficit in listening to the experiences and problems lived by the faithful. This is how de Locht considered it:

$\mathrm{Au}$ cœur d'une Eglise dont la hiérarchie réunie en concile vient de donner l'exemple du dialogue, de la recherche de l'attention aux réalités contemporaines, de la place primordiale du peuple de Dieu, une décision autoritaire, qui tombe comme un couperet, n'accordant aucun crédit aux convictions d'un très grand nombre de conjoints ${ }^{47}$.

On the other hand, obedience may also be a tool used by those who want others to admit their views; de Locht writes :

La plupart du temps, ce fut par exemple le cas après l'encyclique Humance Vitce, les chrétiens qui brandissent l'obéissance pour exiger l'adhésion à la prise de position de l'autorité sont, pour une très large part, ceux qui étaient déjà favorables à cette option. L'obéissance est invoquée par tous ceux qui partagent l'avis de l'autorité et qui font appel à elle pour obtenir le ralliement des autres ${ }^{48}$.

\section{Conclusion}

Noticing, as early as the late 1940s, the growing gap within the Church between those who taught (the clergy) and those who were taught (the laity), de Locht put all his energy in trying to build bridges between these two poles. Without truly achieving

45 P. DE Locht, J'espère être croyant, Paris, Centurion, 1981, p. 42-43.

46 D. Hervieu-Léger, Catholicisme, la fin d'un monde, Paris, Bayard, 2003, p. 169-212.

47 Morale sexuelle et magistère, op. cit., p. 50.

48 P. DE LOCHT, J'espère être croyant, op. cit., p. 33. 
this, he nevertheless managed to maintain in the bosom of the Church believers disappointed by its lack of understanding.

It is obviously difficult to quantify the actual influence of de Locht. His sidelining by the Church from the 1970s closed for him the main paths of thought dissemination usually provided by the Church: he smacked of heresy. Abroad, the Catholic publishing houses did not dare publish his major book: La morale conjugale en recherche ${ }^{49}$.

But other books by de Locht were translated as early as the 1960s in Spanish, German and English, among other languages. However, it is especially in the Frenchspeaking world of Belgium and France that his thought had an impact. Much of his work was done in interpersonal relationships. Much as he was a black sheep, de Locht was, part of a general wave that, within progressive Catholicism, attempted to reinvent the operating procedures of the community of the faithful.

So, even if he did not play an important role in Dutch-speaking Belgium, there are currents of thought similar to his, in major progressive Flemish Catholic publications such as De Maand, Kultuurleven and Streven ${ }^{50}$. Moreover, the questioning of authority belonged very much to the era: in this sense, the actions and commitments of de Locht and his counterparts can be read as echoing a movement that changed the whole of society around what is commonly called "the spirit of 68 ".

As shown by historian Gerd-Rainer Horn, this spirit fertilized but was also nourished by the breath of fresh air produced by the preparation of the Second Vatican Council. De Locht was driven by the revival that impacted all of Western Europe's Christianity and sought to rethink ecclesiology, theology and the place of the Church in society. This movement had already strongly impacted Belgium with the workerpriests. In the 1960s, it manifested itself in the revival of the "base communities" and the involvement in workers' movements ${ }^{51}$.

From this point of view, de Locht was neither a maverick nor a trendsetter. Better than the Church authorities, he worked alongside the transformations of the Catholic world, which, from a wide-angle perspective, ranged from the Catholic Action of the inter-war period to the basic communities founded in the 1970s (Pierre de Locht took part in the foundation of one of them in Brussels: Paroisse libre, Free Parish) and the growing affirmation of laity. As shown by Danièle Hervieu-Léger, Catholics beliefs and commitments after the 1960 s were characterized by a "religious pilgrimism": a voluntary and personal practice, with weak institutional control. In this process, the clergy could have a role to play since it was regularly summoned to give meaning to the rites ${ }^{52}$. This is the function that de Locht embodied.

As an epilogue, we cannot overstate a posteriori the effectiveness of the strategy followed by de Locht. His willingness to create a dialogue between believers and nonbelievers participated in the implementation of Belgian pluralism. This movement

\footnotetext{
${ }^{49}$ UCL, Archives Pierre de Locht, Dossier: Mes livres I, 127.

${ }^{50}$ L. GeVERS, Kerk in de kering: de katholieke gemeenschap in Vlanderen, 1940-1980,

${ }^{51}$ G.-R. HoRn, The spirit of Vatican II: Western European progressive Catholicism in the long sixties, Oxford, Oxford Oxford University Press, 2015.

${ }_{52}$ D. Hervieu-LÉGER, Le pèlerin et le converti: la religion en mouvement, Paris,
} op. cit. Flammarion, 2001. 
has become one of the cardinal principles of the institutions framing the social life of the country. It consists in ensuring the representation of all philosophical trends (religious and non-confessional) in each of these bodies. One of the first one was the Fédération des centres pluralistes de plannings familiaux (Federation of pluralist centers for planned parenthood), created in 1969 at the instigation of Pierre de Locht, in particular. 